University for Business and Technology in Kosovo

UBT Knowledge Center

UBT International Conference

2012 UBT International Conference

Nov 2nd, 9:00 AM - Nov 3rd, 5:00 PM

\title{
Synergic Spaces - MOSQUE
}

Banush Shyqeriu

HU Berlin

Follow this and additional works at: https://knowledgecenter.ubt-uni.net/conference

Part of the Architecture Commons

\section{Recommended Citation}

Shyqeriu, Banush, "Synergic Spaces - MOSQUE" (2012). UBT International Conference. 30.

https://knowledgecenter.ubt-uni.net/conference/2012/all-events/30

This Event is brought to you for free and open access by the Publication and Journals at UBT Knowledge Center. It has been accepted for inclusion in UBT International Conference by an authorized administrator of UBT Knowledge Center. For more information, please contact knowledge.center@ubt-uni.net. 


\title{
Synergic Spaces - MOSQUE
}

\author{
cand. Dr. BANUSH SHYQERIU M.Arch, B.Arch ${ }^{1}$
}

${ }^{1} H U$ Berlin, UBT Prishtina

\begin{abstract}
The congregation Mosque, Mesjid (from Arabic, sujud = prostration) is one of the most important institutions of Muslim world also the predominant architectonic built form of Muslim architecture.The initial aim of this paper is to scrutinize the Mosque as an institution and architectonic space through generative concepts, principles and criteria derived from the eternal idea of the Mosque as a Synergic Space: A place for Worship, a place of Education and a Community centre. By finding a Generic Mosque from an initial and eternal idea derived out of the main Islamic sources, it is possible to deliberate the discourse on Mosque design in the scope of socio-cultural changes as well as advances in design and emerging technologies. Moreover, the dynamics of change in

Muslim societies found the mosque discredited, leading to structural metonyms of Muslim identity and putting the Mosque in a 'crisis' as institution, space, visual expression, symbolism and (un)acceptable as such in a delicate cultural, socio-political and economical Western environment At final, this paper will scrutinize the development of design principles for reframing Mosque visual grammar and language through the use of Islamic patterns as universally legible elements, by transforming them into $3 D$ components and through modularity, dispersion, population, multiplication, deformation, association, dissolution, blending and scaling, creating structure, space and skin as systems that act upon each other. Where structure ends and ornament begins is blurred and a new spatial, structural and cultural performance is revealed. Both constrains on space and visual language of the Mosque tend for giving tangible solution to the Mosque 'crisis' as institution and representative architectural built form, blended together as Synergic Spaces.
\end{abstract}

Keywords: Mosque, Synergic, Spaces, Structure, Ornament, Identity, Visual language, Principles, Eternal idea, Generic 